\title{
ANALISIS KANDUNGAN ASAM ASKORBAT PADA TANAMAN KANGKUNG (Ipomoea reptana Poir), BAYAM (Amaranthus spinosus), dan KETIMUN (Cucumis sativus $\mathrm{L}$ )
}

\author{
Setyo Andi Nugroho ${ }^{1^{\star}}$, Ramadhan Taufika ${ }^{2}$, Ika Lia Novenda ${ }^{3}$ \\ $1^{*}$ Jurusan Produksi Pertanian, Politeknik Negeri Jember \\ 2Jurusan Produksi Pertanian, Politeknik Negeri Jember \\ ${ }^{3}$ Fakultas Keguruan dan IImu Pendidikan, Universitas Jember \\ ${ }^{*}$ Corresponding Author email: andi1746@polije.ac.id
}

\begin{tabular}{ll}
\hline \multirow{2}{*}{$\begin{array}{l}\text { Diterima } \\
\text { Bulan Januari }\end{array}$} & Abstrak \\
\cline { 2 - 3 } 2020 & $\begin{array}{l}\text { Tumbuhan memiliki mekanisme pertahanan terhadap peningkatan senyawa-senyawa } \\
\text { oksidatif yang terbentuk akibat cekaman kekeringan. Pembentuk senyawa tersebut salah } \\
\text { satunya asam askorbat. Askorbat merupakan senyawa metabolit utama pada tumbuhan } \\
\text { yang memiliki fungsi sebagai antioksidan, yang melindungi tanaman dari kerusakan } \\
\text { oksidatif yang dihasilkan dari metabolisme aerobik. Tujuan penelitian melakukan }\end{array}$ \\
Diterbitkan & standarisasi dan menganalisis kandungan Askorbat (ASA) pada daun tanaman kangkung \\
Bulan Februari & (Ipomoea reptana Poir), bayam (Amaranthus spinosus) dan ketimun (Cucumis sativus, \\
2020 & L). Metode yamg digunakan Sampel daun sebanyak 0,5 g digerus dengan asam \\
& metafosforik 5\%. Larutan yang diperoleh dititrasikan dengan dichlorophenol-indophenol \\
Keyword: & (DCIP) 0,8 g/l. Perlakuan analisis kandungan asam askorbat (ASA) pada jaringan \\
Askorbat, & tanaman ini yang memiliki kandungan asam askorbat terbesar pada tanaman ketimun \\
kangkung, bayam, & (Cucumis sativus L) sebesar 69855,85; kemudian diikuti tanaman kangkung (Ipomoea \\
ketimun & reptana Poir) sebesar 66517,24 dan terakhir pada bayam (Amaranthus spinosus) sebesar
\end{tabular}

\section{PENDAHULUAN}

Kekeringan merupakan kondisi alamia yang dihadapi tanaman dalam siklus hidupnya. Kondisi kekeringan merupakan salah satu faktor yang menekan pertumbuhan dan perkembangan tanaman di seluruh dunia (Schwanz \& Polle 2001). Pada tumbuhan, gejala pertama yang disebabkan oleh cekaman kekeringan ialah penurunan potensial air kemudian diikuti oleh penutupan stomata (Chaves 1991; Brodribb \& Holbrook 2003) sehingga menyebabkan pengambilan $\mathrm{CO}_{2}$ untuk fotosintesis terhambat yang akhirnya menurunkan laju fotosintesis (Lawlor 2002; Neumann 2008). Apabila kekeringan berlanjut maka menyebabkan pertumbuhan fase generatif terganggu, terjadinya senesense dan bahkan kematian (Neumann 2008).

Tumbuhan memiliki mekanisme pertahanan terhadap peningkatan senyawa-senyawa oksidatif yang terbentuk akibat cekaman kekeringan dan aplikasi paraquat. Pembentukan senyawa antioksidan, seperti askorbat (ASA), $\alpha$-tokoferol dan glutation, merupakan salah satu sistem pertahanan tanaman tersebut. Selain itu, peningkatan karotenoid (Munné-Bosch et al. 1999) dan aktivitas enzim antioksidan, seperti enzim superoksida dismutase (SOD), askorbat peroksidase (APX) (Prohazkova et al 2001), glutation reduktase (GR) (Keleş \& Öncel 2002) juga bisa terjadi jika senyawa-senyawa oksidatif terbentuk. Oleh karena itu perlu dilakukan penelitian yang berhubungan dengan dampak cekaman kekeringan dan paraquat terhadap perubahan aktivitas enzim-enzim seperti SOD, APX dan ASA khususnya pada tanaman budidaya masih diperlukan.

Hamim (2005) menyatakan bahwa pada tahap awal, kekeringan menyebabkan berkurangnya pembukaan stomata untuk meminimalisir kehilangan air di bawah kondisi cahaya berlebihan. Peristiwa ini mengakibatkan terjadinya penurunan konsentrasi $\mathrm{CO} 2$ intrasel, sehingga tanaman mengalami overreduksi pada transfer elektron fotosintesis (Berkowitz 1998). Overreduksi ini terjadi karena pembentukan NADPH pada reaksi terang tidak diimbangi oleh pemakaian NADPH pada reaksi gelap karena penurunan konsentrasi $\mathrm{CO} 2$ intrasel. Hal ini mengakibatkan terbentuknya reactive oxygen species (ROS) yang diawali dengan pengikatan elektron pada transpor elektron fotosintesis oleh oksigen. Proses selanjutnya akan terbentuk berbagai bentuk senyawa ROS seperti; superoksida $\left(\mathrm{O}_{2-}\right)$, singlet oksigen $\left(\cdot \mathrm{O}_{2}\right)$, radikal hidroksil $(\mathrm{OH})$ dan hidrogen peroksida $\left(\mathrm{H}_{2} \mathrm{O}_{2}\right)$ (Mckersie and Leshem, 1994). Senyawa ROS ini akan dapat menimbulkan kerusakan pada tanaman (Aroca et al. 2001). Jika hal ini dibiarkan, maka lama kelamaan tanaman akan mati (Apel \& Hirt 2004).

ASA atau vitamin $\mathrm{C}$ merupakan asam organik dengan kemampuan antioksidan. ASA dapat larut dalam air dan sangat mudah dioksidasi yaitu sebagai senyawa reduktan. ASA akan rusak 
ketika ditempatkan pada cahaya atau panas yang akan berubah dalam bentuk teroksidasi yaitu asam dehidroaskorbat. Tujuan penelitian melakukan standarisasi dan menganalisis kandungan Askorbat (ASA) pada daun tanaman kangkung (Ipomoea reptana Poir), bayam (Amaranthus spinosus), dan ketimun (Cucumis sativus, L)

\section{LANDASAN TEORI}

\section{Pengaruh Kekeringan terhadap Pertumbuhan Tanaman}

Kekeringan didefinisikan sebagai periode waktu tanpa turun hujan. Cekaman kekeringan terjadi ketika kecukupan air yang tersedia di dalam tanah karena masukan air (oleh hujan atau irigasi) telah berkurang yang disebabkan oleh transpirasi dan evaporasi. Kekeringan memiliki pengaruh yang besar pada pertumbuhan tanaman, hasil, dan kualitas. Dampak awal dari cekaman kekeringan adalah terjadinya kehilangan turgor (termasuk layu) yang dapat mempengaruhi perluasan sel dan ukuran sel. Kehilangan turgor terlihat pada kebanyakan tumbuhan yang peka pada cekaman kekeringan. Kekeringan juga dapat mempertinggi pengguguran daun atau absisi, mengurangi luas total daun dan berpotensi memperbaiki kesegaran daun pada lingkungan air yang terbatas, dan perpanjangan akar lebih dalam (O'toole \& Garrity 1984).

Mathius et al. (2004) menyatakan bahwa secara morfologis pengaruh cekaman kekeringan terlihat pada pertumbuhan vegetatif, terutama pada luas daun, pertumbuhan tunas baru, nisbah tajukakar. Pada fase generatif menyebabkan pembungaan tidak normal, aborsi embrio, dan perkembangan biji dan buah tidak normal.

\footnotetext{
Asam Askorbat

Asam askorbat atau vitamin $\mathrm{C}$ merupakan salah satu bentuk antioksidan yang secara alami terdapat pada tumbuhan. Askorbat merupakan senyawa metabolit utama pada tumbuhan yang memiliki fungsi sebagai antioksidan, yang melindungi tanaman dari kerusakan oksidatif yang dihasilkan dari metabolisme aerobik, fotosintesis dan berbagai polutan. Askorbat juga merupakan kofaktor untuk beberapa enzim hidroksilase (misalnya prolyl hidroksilase) dan violaxanthin deepoxidase. Askorbat berada di dinding sel di mana ia adalah baris pertama pertahanan terhadap ozon (Smirnoff 1996).

Askorbat memenuhi banyak fungsi penting pada biologi tanaman (Noctor and Foyer 1998). Askorbat juga digunakan sebagai ko-faktor untuk violaxanthin de-epoxidase pada siklus xanthophyll. Proses ini dilibatkan dalam perlindungan pelepasan
}

penyerapan cahaya dalam bentuk panas dan bisa diukur sebagai NPQ dari klorofil fluorescence (Sonja et al. 2001). Pada cekaman kekeringan kandungan ASA mengalami peningkatan seiring bertambahnya periode cekaman. Bejana et al. (1998) menjelaskan bahwa antioksidan seperti ASA dan glutation mengalami peningkatan di kloroplas pada kondisi kekeringan. Peningkatan ASA pada tanaman berfungsi untuk mereduksi radikal bebas yang terbentuk akibat cekaman oksidatif (Mc Kersie \& Leshem 1994). ASA yang disintesis di sitosol akan bereaksi dengan $\mathrm{H}_{2} \mathrm{O}_{2}$ sehingga menghasilkan MDHA dan air. Kandungan ASA juga meningkat akibat perlakuan paraquat. ASA sebagai senyawa antioksidan dapat berinteraksi dengan membran plasma dan mendonorkan elektronnya ke radikal $\alpha$ tocopheroxyl dan aktivitas trans-membran plasma oksidoreduktase. Recycling $\alpha$ tocopheroxyl dapat membantu melindungi membran plasma dari peroksidasi (May 1999).

\section{MATODE PENELITIAN}

\section{Alat dan Bahan}

Bahan penunjang yang digunakan dalam penelitian adalah bahan sampel daun dari tanaman yang tercekam kekeringan yaitu pada tanaman kangkung (Ipomoea reptana Poir), bayam (Amaranthus spinosus), dan ketimun (Cucumis sativus, L). Bahan kimia yang digunakan asam metafosforik, larutan dichlorophenol-indophenol (DCIP) 0,8 g/l, dan larutan askorbat murni.

Peralatan yang digunakan dalam penelitian ini adalah corong, kertas saring, mortar, pipet ukur, alat set titrasi, dan tabung reaksi.

\section{Analisis kandungan Askorbat}

Sampel daun sebanyak $0,5 \mathrm{~g}$ digerus dengan asam metafosforik $5 \%$ untuk mencegah terjadinya oksidasi dari asam askorbat, kemudian hasil gerusan disaring dengan menggunakan kertas saring. Larutan yang diperoleh dititrasikan dengan dichlorophenol-indophenol (DCIP) 0,8 g/l. Sebelum digunakan titrasi, larutan DCIP distandarisasi dengan larutan asam askorbat murni, yaitu $1 \mathrm{ml}$ larutan asam askorbat (4 mg/l) dan $9 \mathrm{ml}$ asam metafosforik $5 \%$. Titrasi dihentikan ketika terjadi perubahan warna larutan menjadi warna pink.

1. Kandungan Askorbat diperoleh standarisasi larutan ASA murni (4 mg ASA murni $=1 \mathrm{ml}$ DCIP).

mg ASA / 1ml DCIP = 4 mg ASA murni/ DCIP yang dititrasi (ml).

2. Kandungan ASA daun (ASA/g sampel daun) Mg ASA x Total vol ekstrak air (ml) x $100 \mathrm{Vol}$ yang dititrasikan $\mathrm{g}$ sampel 


\section{HASIL DAN PEMBAHASAN}

Dalam Analisis kandungan Asam askorbat (ASA) pada tanaman kangkung (Ipomoea reptana Poir), bayam (Amaranthus spinosus), dan ketimun (Cucumis sativus, L) akan disajikan pada tabel di bawah ini.

Dalam pengamatan kali ini mengamati kandungan asam askorbat (ASA) pada tanaman kangkung (Ipomoea reptana Poir), bayam (Amaranthus spinosus), dan ketimun (Cucumis sativus, L). Selain itu juga dibuat kontrol pada masing-masing tanaman tersebut. Sebelum perlakuan ini masing-masing tanaman dilakukan cekaman air atau stres air. Pertumbuhan sel sangat sensitif terhadap stres air. Penghambatan pembesaran sel terjadi karena penurunan turgor sel yang berakibat bagian tanaman yang dibentuk berukuran kecil. Pengaruh kekurangan air selama tingkat perkembangan vegetatif ialah berkembangnya daun-daun yang lebih kecil. Selama perkembangan vegetatif kekurangan air sekecil apapun dapat mengurangi laju pelebaran daun dan luas daun pada tingkat perkembangan berikutnya (Islami \& Utomo, 1995). RuBP pada kekeringan ringan. Penurunan $\mathrm{CO} 2$ intrasel memperkuat kemungkinan hambatan stomata dalam menghambat laju fotosintesis pada fase awal stres air. Hal ini berkaitan dengan perubahan metabolik dalam kehilangan potensial fotosintesis pada fase ini (Lawlor 2002). Ketika penutupan stomata terjadi, dengan sendirinya $\mathrm{CO} 2$ yang masuk melalui stomata akan menurun. Seperti diketahui bahwa $\mathrm{CO} 2$ dibutuhkan dalam reaksi kabon fotosintesis (siklus kalvin), sehingga penurunan $\mathrm{CO} 2$ ini tentunya akan menurunkan laju fotosintesis.

Proses selanjutnya NADPH yang digunakan pada reaksi karbon fotosintesis akan menumpuk akibat penurunan konsentrasi $\mathrm{CO} 2$ (Tezara et al. 1999). Pada keadaan ini tanaman akan mengalami overeduksi pada transpor elektron fotosintesis, yang nantinya akan menginduksi terbentuknya reactive oxygen species (ROS).

Kita mengetahui bahwa tanaman bayam yang dianalisis kandungan asam askorbat termasuk tanaman C4. adaptasi pada kawasan panas, keadaan kering dan lembab. Kranz anatomi pada tanaman C4 seludang berkas berdinding tebal dan memiliki banyak kloroplast, mitokondria serta organel yang lain. Vacuola pusat berukuran lebih kecil (Salisbury \& Ross 1992). Walaupun begitu tanaman C4 pada bayam memiliki mekanisme proses fotosintesis yang berbeda dengan tanaman $\mathrm{C} 3$ seperti kangkung dan mentimun yang diuji dalam analisis kandungan asam askorbat. Tanaman $\mathrm{C} 4$ cenderung lebih bisa mempertahankan konsentrasi $\mathrm{CO} 2$ daun pada kondisi defisit air, sehingga laju fotosintesis bisa dipertahankan lebih lama. Hal ini terkait dengan aktivitas rubisko sebagai enzim yang mereduksi CO2 dalam siklus kalvin, dimana pada tanaman C4 rubisko hanya terdapat pada sel-sel seludang berkas, sehingga tidak terjadi persaingan antara $\mathrm{O} 2$ dan $\mathrm{CO} 2$ ketika konduktan stomata menurun.

Mekanisme adaptasi tanaman C4 terutama pada bayam ini ada mekanisme dimana tumbuhan C4 memiliki dua jenis sel fotosintetik yang jelas berbeda, yaitu sel seludang berkas pembuluh dan sel mesofil. Sel seludang berkas pembuluh disusun menjadi kemasan yang sangat padat di sekitar berkas pembuluh. Di antara seludang berkas pembuluh dan permukaan daun terdapat sel mesofil yang disusun lebih longgar. Siklus Calvin terbatas pada kloroplas seludang berkas pembuluh. Akan tetapi, siklus ini didahului oleh masuknya $\mathrm{CO} 2$ ke dalam senyawa organik dalam mesofil. Langkah pertama ialah penambahan $\mathrm{CO} 2$ pada fosfoenolpiruvat (PEP) untuk membentuk produk berkarbon empat, yaitu oksaloasetat. Enzim PEP karboksilase menambahkan $\mathrm{CO} 2$ pada PEP. Dibandingkan dengan rubisko, PEP karboksilase memiliki afinitas yang jauh lebih tinggi terhadap $\mathrm{CO} 2$. Oleh sebab itu, PEP karboksilase dapat memfiksasi $\mathrm{CO} 2$ secara efisien ketika rubisko tidak dapat melakukannya, yakni ketika hari panas dan kering dan stomata tertutup sebagian, menyebakan konsentrasi $\mathrm{CO} 2$ dalam daun berkurang dan konsentrasi O2 meningkat. Setelah CO2 difiksasi, sel mesofil mengirim keluar produk berkarbon empatnya ke sel seludang berkas pembuluh melalui plasmodesmata. Dalam sel seludang berkas pembuluh, senyawa berkarbon empat melepaskan $\mathrm{CO} 2$ yang diasimilasi ulang ke dalam materi organik oleh rubisko dan siklus Calvin. Akibatnya, sel mesofil akan memompa $\mathrm{CO} 2$ ke dalam seludang berkas pembuluh, mempertahankan konsentrasi $\mathrm{CO} 2$ dalam sel seludang berkas pembuluh cukup tinggi agar rubisko dapat menerima karbon dioksida, bukan oksigen. Dengan cara ini, fotosintesis akan meminimumkan fotorespirasi dan meningkatkan produksi gula. Adaptasi ini sangat bermanfaat dalam daerah panas dengan cahaya matahari yang banyak, dan di lingkungan seperti inilah sekarang tanaman ini tumbuh subur. Tanaman C4 saat siang hari mereka tidak membuka stomatanya secara penuh untuk mengurangi kehilangan air melalui evaporasi/transpirasi. Ini berakibat terjadinya penurunan jumlah $\mathrm{CO} 2$ yang masuk ke stomata. Logikanya hal ini menghambat laju fotosintesis. Ternyata para tumbuhan ini telah mengembangkan cara yang cerdas untuk menjaga agar laju fotosintesis tetap normal meskipun stomata tidak membuka penuh. 
Tabel 1. Kandungan Asam Askorbat pada berbagai tanaman

\begin{tabular}{|c|c|c|c|c|c|c|}
\hline No. & Perlakuan & $\begin{array}{l}\text { Volume } \\
\text { Ekstrak }\end{array}$ & $\begin{array}{l}\text { Volume } \\
\text { Titran } \\
\text { DCIP } \\
\end{array}$ & $\begin{array}{l}\text { MG ASA } \\
\text { standar }\end{array}$ & $\begin{array}{c}\text { kandungan } \\
\text { ASA }\end{array}$ & $\begin{array}{c}\text { Rata-rata } \\
\text { ASA }\end{array}$ \\
\hline 1. & Bayam kontrol 1 & 6,3 & 15,5 & 308 & 25037,42 & \\
\hline 2. & Bayam kontrol 2 & 6,7 & 15,6 & 308 & 26456,41 & 25746,91 \\
\hline 3. & Bayam tercekam 1 & 7,4 & 11,5 & 308 & 39638,26 & \\
\hline 4. & Bayam tercekam 2 & 6,8 & 11 & 308 & 38080,00 & 38859,13 \\
\hline 5. & Kangkung kontrol 1 & 6,6 & 7,5 & 308 & 54208,00 & \\
\hline 6. & Kangkung kontrol 2 & 6,5 & 7 & 308 & 57200,00 & 55704,00 \\
\hline 7. & Kangkung tercekam 1 & 6,5 & 5,8 & 308 & 69034,48 & \\
\hline 8. & Kangkung tercekam 2 & 8 & 7,7 & 308 & 64000,00 & 66517,24 \\
\hline 9. & Mentimun kontrol 1 & 5,5 & 11,2 & 308 & 30250,00 & \\
\hline 10. & Mentimun kontrol 2 & 7,3 & 9,2 & 308 & 48878,26 & 39564,13 \\
\hline 11. & Mentimun tercekam 1 & 6,2 & 5,7 & 308 & 67003,51 & \\
\hline 12. & Mentimun tercekam 2 & 7,2 & 6,1 & 308 & 72708,20 & 69855,85 \\
\hline
\end{tabular}

Ini menandakan tanaman ini dalam kondisi tercekam mampu menghasilkan asam askorbat lebih besar dibandingkan tanaman bayam yang tanaman tersebut tergolong tanaman c4 yang mampu beradaptasi dengan cekaman air, tetapi pada tanaman kangkung ini dia mengeluarkan dua kali lebih besar asam askorbat pada pecobaan kali ini.

Tanaman kangkung (Ipomoea reptana Poir) tergolong tanaman C3 sehingga dia membutuhan asam askorbat yang besar dalam rangka adaptasi terhadap cekaman air. Secara fisiologis ada perbedaan yang menyolok antara tumbuhan $\mathrm{C} 3$ dan $\mathrm{C} 4$ dalam menghadapi cekaman kekeringan. Pada tumbuhan C3, ketika stomata menutup sebagai akibat kekeringan, fotosintesis neto akan menurun dengan cepat, sedangkan fotorespirasi akan meningkat (Drake et al. 1997). Hal ini berkaitan dengan karakteristik dari enzim fotosintetik, RuBP karboksilase (Rubisco) yang selain mengikat CO2 juga dapat berikatan dengan oksigen dalam proses fotorespirasi, dan keadaan ini terjadi khususnya ketika rasio $\mathrm{CO} 2 / \mathrm{O} 2$ menurun akibat penutupan stomata (Hamim 2005). akan tetapi tumbuhan $\mathrm{C} 4$ relatif lebih tahan dengan kondisi cekaman kekeringan dari pada C3. Dalam keadaan cekaman kekeringan tumbuhan C3 umumnya memiliki kadar air relatif daun yang lebih rendah dari pada tumbuhan $\mathrm{C} 4$. Hal ini mungkin teknik dengan karakteristik tumbuhan $\mathrm{C} 4$ yang cukup efisien dalam pemanfaatan air (Hamim, 2005). Tanaman C3 ini dapat mengasimilasi CO2 secara langsung melalui jalur fotosintesis (Miyao 2002) jalur ini dikenal dengan sikus C3 karena senyawa stabil yang terbentuk pertama kali dalam pengikatan $\mathrm{CO} 2$ merupakan senyawa berkarbon 3 yaitu senyawa 3-fosfogliserat (PGA) atau dikenal dengan siklus kelvin (Taiz \& Zeiger 1991) tumbuhan dapat hidup dengan baik pada suhu rendah, yaitu pada suhu kurang dari $22^{\circ} \mathrm{C}$ ( Koji \& Winslow 2002).

Selain mekanisme fisiologis, tumbuhan juga memiliki kemampuan adaptasi secara morfologis dan anatomis. Pada keadaan cekaman kekeringan terdapat dua mekanisme utama yang mungkin terjadi pada tumbuhan, yaitu: (a) tumbuhan berusaha menghindari cekaman, baik dengan cara melakukan perubahan struktur morfologi dan anatomi, maupun dengan meningkatkan efisiensi penggunaan air dengan cara mengatur laju transpirasi, dan (b) meningkatkan toleransi terhadap cekaman kekeringan melalui perubahan kimia sel (Meyer \& Genty 1998).

Pada pengamatan yang terakhir yaitu mengamati ketimun (Cucumis sativus, L) dimana asam askorbat pada tanaman perlakuan cekaman sebesar 69855,85 lebih besar dibandingkan dengan tanaman kontrol sebesar 39564,13. Dari data ini dapat kita lihat bahwa jarak antara tanaman kontrol dengan perlakuan cekaman ini dua kalinya. Artinya kondisi dari tanaman ketimun ini melakukan adaptasi sehingga dia mengeluarkan asam askorbat dua kali tanaman kontrol. Tanaman ketimun ini kalau kita lihat banyak mengeluarkan asam askorbat mengingat tanaman ini tidak tahan terhadap cekaman air. Tanaman ketimun ini tergolong tanaman C3 dia tidak toleran dengan kondisi panas ataupun kekeringan. Panas yang berlebihan dapat mengganggu dan akhirnya membunuh suatu tumbuhan dengan cara mendenaturasi enzimenzimnya. Panas ini melakukan mekanisme kekurangan air.

Kekurangan air pada tanaman dapat menghambat laju fotosintesis, karena turgiditas sel penjaga stomata akan menurun. Hal ini menyebabkan stomata menutup (Lakitan 1995). Penutupan stomata sebagai respon cekaman kekeringan diawali dengan sintesis asam absisik 
(ABA) (Mohammadkhani \& Heidari 2008). Penutupan stomata pada daun akan mengurangi laju penyerapan $\mathrm{CO} 2$ sehingga akan mengurangi laju fotosintesis (Goldsworthy \& Fisher 1992). Perubahan ini juga akan mempengaruhi absorpsi dan translokasi hara mineral, transpirasi serta translokasi fotosintat (Mathius et. al 2001).

Untuk menghadapi efek negatif dari akumulasi Aktive Oxygen Spesies AOS, tumbuhan memiliki suatu mekanisme sistem pertahanan antioksidan yang efisien, melibatkan baik enzimenzim maupun senyawa-senyawa non enzim (Loggini et al. 1999). Mekanisme pertahanan ini pada dasarnya dapat dikelompokan menjadi tiga, yaitu: (1) reaksi yang melibatkan metabolit tertentu khususnya asam askorbat dan glutation, (2) mekanisme penyelamatan AOS yang melibatkan enzim-enzim seperti superoksida dismutase (SOD), katalase (CAT), glutation peroksidase (GPX) dan askorbat peroksidase (APX), dan (3) mekanisme yang melibatkan enzim-enzim untuk regenerasi antioksidan seperti glutation reduktase (GR) dan monodehidroascorbate reduktase (MDHAR) (Foyer et al. 1997; Noctor \& Foyer 1998; Niyogi 1999; Roxas et al. 2000). Tanaman yang mengalami stress oksidatif karena adanya tekanan dari lingkungan baik itu berupa cekaman kekeringan, temperatur yang tinggi atau faktor lain, maka tumbuhan akan menunjukkan overekspresi dari enzim-enzim yang berperan dalam perlindungan dari tekanan oksidatif tersebut yaitu enzim-enzim antioksidan.

Pada saat energi cahaya matahari tinggi dan tanaman di bawah kondisi cekaman kekeringan, maka akan kelebihan exitasi energi, tanaman akan melakukan fotoproteksi dengan menghamburkan atau melepaskan energi yang tereksitasi dan sebagian ditransfer ke oksigen untuk membentuk singlet oksigen $\left(\mathrm{O}_{2}\right)$. Terhambatnya laju transfer elektron juga berperan penting dalam mereduksi molekul oksigen dan menghasilkan superoxida $\left(\mathrm{O}_{2}\right)$ yang kemudian oleh enzim SOD akan direduksi menjadi $\mathrm{H}_{2} \mathrm{O}_{2}$ dan didetoksifikasi dalam siklus "ascorbat-glutathion" membentuk H2O. Siklus “ascorbat-glutathion”(Tausz et al. 2004).

\section{PENUTUP}

\section{Kesimpulan}

kesimpulan dari penelitian adalah analisis kandungan asam askorbat (ASA) pada tanaman kangkung (Ipomoea reptana Poir), bayam (Amaranthus spinosus), dan ketimun (Cucumis sativus, L) adalah Perlakuan analisis kandungan asam askorbat (ASA) pada jaringan tanaman ini yang memiliki kandungan asam askorbat terbesar pada tanaman ketimun (Cucumis sativus, L) sebesar 69855,85; kemudian diikuti tanaman kangkung (Ipomoea reptana Poir) sebesar 66517,24 dan terakhir pada bayam (Amaranthus spinosus) sebesar 38859,13. Dan mg ASA standar 308.
Dalam analisis kandungan asam askorbat (ASA) bahwa tanaman yang tergolong C3 yaitu pada tanaman kangkung (Ipomoea reptana Poir) dan ketimun (Cucumis sativus, L); sedangkan untuk tanaman C4 pada tanaman bayam (Amaranthus spinosus)

\section{REFERENSI}

Apel K, Hirt H. 2004. Reactive oxygen species: metabolism, oxydative stress, and signal transduction. Plant Biol 55:373-399.

Aroca R, Juan JI, Manuel SD. 2001. Photosynthetic characteristics and protective mechanisms against oxidative stress during chilling and subsequent recovery in two maize varieties differing in chilling sensitivity. Plant Sci 161:719-726.

Becana M, Moran JF, Ormaetxe. 1988. Irondependent oxygen free radical generation in plants subjected to environmental stress: toxicity and antioxidant protectio. Plant and Soil. 201: 137-147

Berkowitz GA. 1998. Water and Salt Stress. In: Raghavendra AS (ed). Photosynthesis: A Comprehensive Treatise. Cambridge: Cambridge University Pr; p. 226-237.

Brodribb TJ, Holbrok NM. 2003. Stomatal closure during leaf dehydration, correlation with other leaf physiological traits. Plant Physiol 132:2166-2173.

Chaves M. 1991. Effect water deficit on carbon assimilation. J Exp Bot 42:1-6.

Drake BG, Miquel A, Gonzàlez M. 1997. MORE EFFICIENT PLANTS: A Consequence of Rising Atmospheric $\mathrm{CO}_{2}$ ?. Plant Physiology and Plant Molecular Biology .48:609-639

Foyer CH, Descourvieres P, Kunert KJ (1994). Photoxidative stress in plants. Plant Physiol. 92: 696-717.

Goldsworthy, P.R. dan N.M. Fisher. 1992. Fisiologi Tanaman Budidaya Tropik (diterjemahkan oleh Tohari). Gajah Mada University Press, Yogyakarta.

Hamim. 1995. Toleransi kedelai terhadap cekaman kekeringan: Pendekatan morfologi dan fisiologi [tesis]. Bogor: Program Pascasarjana, Instutut Pertanian Bogor.

Hamim. 2005. Respon pertumbuhan spesies pertumbuhan spesies C3 dan C4 terhadap cekaman kekeringan dan konsentrasi $\mathrm{CO}_{2}$ tinggi. Biosfera 22:105-113

Islami, T. dan W.H. Utomo. 1995. Hubungan Tanah, Air dan Tanaman. IKIP Semarang Press, Semarang.

Keleş Y, Öncel I. 2002. Response of antioxidative defence system to temperature and water stress combination in wheat seedlings. Plant Sci 163:783-790. 
Koji S, Winslow RB. Cellular and Subcellular Localization of Phototropin 1. The Plant Cell, 14:1723-1735

Lakitan, B. 1995. Dasar-dasar Fisiologi Tumbuhan. PT. Raja Grafindo Persada, Jakarta.

Lawlor DW. 2002. Limitation to photosynthesis in water-stressed leaves: stomata vs metabolism and the role of ATP. Ann Bot 89:871-885.

Loggini B, Scartazza A, Brugnoli E, Navari-Izzo F (1999) Antioxidant defense system, pigment composition and photosynthetic efficiency in two wheat cultivars subjected to drought. Plant Physiol. 119:1091-1099.

Mathius, N.T., G. Wijana, E. Guharja, H. Aswindinnoor, Y. Sudirman, dan Subronto. 2001. Respon Tanaman Kelapa Sawit (Elaeis guineensis Jacq.) terhadap Cekaman Kekeringan. Menara Perkebunan 69 : 29 45.

May Jm. 1999. Is ascorbic asid an antioxidant for plasma membrane?. Faseb Journal 13:9951006.

McKersie BD, Leshem YY. 1994. Stress and Stress Coping in Cultivated Plants. Netherlands: Kluwer Academic Publishers.

Meyer S, Genty B. 1998. Mapping intercellular CO2 mole fraction (Ci) in Rosa rubiginosa leaves fed with abscisic acid by using chlorophyll fluorescence imaging: significance of $\mathrm{Ci}$ estimated from leaf gas exchange. Plant Physiol 116:947-957.

Miyao M. 2002. Molecular evolution and genetic engineering of $\mathrm{C} 4$ photosynthetic enzymes. $J$ Exp Bot. 54: 179-189

Mohammadkhani, N. and R. Heidari. 2008. Water Stress Induced Stomatal Closure in Two Maize Cultivars. R. J. Bio. Sci. 3 (7) : 750 754.

Munné-Bosch S, Schwarz K, alegre L. 1999. Enhaced formation of $\alpha$-tokoferol and highlyoxidizedabieten diterpenes in waterstressed rosemary plants. Plant Physiol 121:1061-1068.

Neumann PM. 2008. Coping mechanisms for crop plants in drought-prone environments. Ann Bot 101:901-907.

Niyogi, K.K. 1999. Photoprotection revisited: Genetic and molecular approaches. Annu. Rev. Plant Physiol. Plant Mol. Biol. 50: 333359
Noctor G, Foyer GH. 1998. Ascorbate and glutathione: Keeping active oxygen under control. Plant Physiol 49:249-279.

O'toole, JC, Garrity DP. 1984. Upland Rice SoilPlant-Water Relationship. An Overview of Upland Rice Research.International Rice Research Institut. Manila. 1:395-411.

Prohazkova D, Sairam RK, Srivastava GC, Singh DV. 2001. Oxidative stress and antioxidant activity as the basis of senescence in maize leaves. Plant Sci 161:765-771.

Roxas, V.P., S.A. Lodhi, D.K. Garrett, J.R. Mahan and R.D. Allen, 2000. Stress tolerance in transgenic tobacco seedlings that overexpress glutathione S-transferase/glutathione peroxidase. Plant Cell Physiol., 41: 12291234

Salisbury \& Ross, 1992. Plant Physiology. 4th ed. Terjemahan Diah R Lukman \& Sumaryono Jilid 2. ITB Bandung.

Schwanz P, Polle A. 2001. Differential stress responses of antioxidative systems to drought in penduculate oak (Quercus robur) and maritime pine (Pine pinaster) grown under high CO2 concentration. $J$ Exp Bot 52(354):133-143.

Smirnoff N. 1996. The function and metabolism of ascorbic acid in plants. [botanical briefing]. Ann Bot 78:661-669.

Sonja D, Veljovic-Jovanovic, Cristina P, Graham N, Christine HF. 2001. Low askorbic acid in the vtc-1 mutant of Arabidopsis is associated with decreased growth and intracellular redistribution of the antioxidant system. Plant Physiol 127:426-435.

Taiz L, Zeiger E. 2002. Plant Physiology. Sunderland: Sinauer Associates. hal 690.

Tausz M, Wonisch A, Peters J, Jimenez MS, Morales D, Grill D.2004. Short-term changes in free-radical scavengers and chloroplast pigments in Pinus canariensis needles as affected by mild drought stress. Journal of Plant Physiology. 158, 213-219.

Tezara W, Mitchell V, Driscoll SP, Lawlor DW. 2002. Effects of water deficit and its interaction with $\mathrm{CO} 2$ supply on the biochemistry and physiology of photosynthesis in sunflower. $J$ Exp Bot 53:1781-1791 